\title{
Effects of subarachnoid haemorrhage on intracranial prostaglandins
}

\author{
V WALKER, JD PICKARD, P SMYTHE, S EASTWOOD, S PERRY \\ From the University Department of Chemical Pathology and Human Metabolism and Wessex Neurological \\ Centre, Southampton General Hospital, Southampton, UK
}

SUMmaRY Prostaglandins $E_{2}, F_{2} \alpha, 6$ oxo $F_{1} \alpha$ and thromboxane $B_{2}$ increased in cisternal CSF following mock subarachnoid haemorrhage in dogs, particularly $\mathrm{PGE}_{2}(\mathrm{X} 25 \cdot 5)$. Concentrations were increased also in lumbar CSF of five patients some 8 days after subarachnoid haemorrhage. Subarachnoid haemorrhage did not alter the production of prostaglandins by dog whole cortex or choroid plexuses in vitro, but production by pooled dissected cerebral arteries of $\mathrm{PGE}_{2}$ was increased and of 6 oxo $F_{1} \alpha$ was decreased. Intravenous indomethacin decreased prostaglandin production by cerebral tissues, and caused a marked decrease in the prostacyclin metabolite in CSF. The implications of our findings for the aetiology of cerebral vasospasm are discussed.

How far can excessive production of Thromboxane $\mathrm{A}_{2}, \mathrm{PGF}_{2} \alpha$ or $\mathrm{PGE}_{2}$, or defective synthesis of prostacyclin explain the cerebrovascular changes following subarachnoid haemorrhage? Delayed cerebral ischaemia occurs naturally after subarachnoid haemorrhage but often appears to be aggravated by surgical intervention, particularly when this is performed during the first week after rupture of the aneurysm. This period of greatest risk coincides with the development of cerebral arterial vasospasm which is seldom seen prior to 3 days after the bleed but becomes maximal around the end of the first week and declines thereafter. ${ }^{1}$ The capricious relationship between spasm and neurological deficit may reflect the ability of the individual's cerebral circulation to accommodate to such narrowed vessels: tissue ischaemia may be exacerbated when a further stress is applied such as a period of hypotension. ${ }^{23}$

Cerebral vasospasm may be the end result of competition between the changing properties and synthetic capacity of the cerebral endothelium and vascular smooth muscle cell, and the evolving pattern of substances released from clotted blood to which they are exposed. ${ }^{4}$ Human cerebral vasospasm is refractory to any known pharmacological blocker or

Address for reprint requests: Mr JD Pickard, Wessex Neurological Centre, Shirley, Southampton SO9 4XY, UK.

Received 4 September 1982

Accepted 4 October 1982 synthesis inhibitor. ${ }^{1}$ There is a relationship between periarterial haematoma and subsequent arterial narrowing, but the relationship is not a simple one. ${ }^{5}$ Lipid peroxidation may be involved, leading to damage to both endothelium and vascular smooth muscle cell. ${ }^{6}$ Arachidonic acid derivatives such as prostacyclin (Ref 7 for review) may have a physiological role in the control of cerebral blood flow, 89 and part of the sequence of events precipitating cerebral vasospasm may be prostacyclin deficiency. 10 Two recent reports suggest that cerebral arterial generation of prostacyclin in vitro is impaired after subarachnoid haemorrhage. ${ }^{11} 12$ Unfortunately the problems of measuring the concentrations of the different cyclo-oxygenase and lipoxygenase products in the different compartments of the human brain are formidable. ${ }^{13}$ Our present purpose was to obtain quantitative data on changes in CSF prostaglandins/ Thromboxane $\mathrm{B}_{2}\left(\mathrm{TXB}_{2}\right)$ following subarachnoid haemorrhage in both man and dog, and to compare these results with the in vitro production of prostaglandins $/ \mathrm{TXB}_{2}$ by cerebral cortex, choroid plexus and cerebral arteries from the dog. The opportunity was taken to observe the acute effects of indomethacin on intracranial prostaglandin synthesis.

\section{Materials and methods}

\section{Materials}

Standard prostaglandins (PG) $E_{2}, 6$ oxo $F_{1} \alpha, F_{2} \alpha$ (tromethamine salt) and $\mathrm{TXB}_{2}$ were gifts from $\mathrm{Dr}$ John Pike, the Upjohn Co, Kalamazoo, Michigan, USA ; ${ }^{3} \mathrm{H}$ PG 
$\mathrm{E}_{2}$ (specific Activity $\left.160 \mathrm{Ci} / \mathrm{mmol}\right),{ }^{3} \mathrm{H} 6$ oxo PG $\mathrm{F}_{1} \alpha(150$ $\mathrm{Ci} / \mathrm{mmol})$ and ${ }^{3} \mathrm{H}$ PG $F_{2} \alpha(180 \mathrm{Ci} / \mathrm{mmol})$ were from the Radiochemical Centre, Amersham. ${ }^{3} \mathrm{H} \mathrm{TXB}_{2}(125 \mathrm{Ci} /$ mmol) was from New England Nuclear, Boston, Mass USA. Antisera to $\mathrm{PGE}_{2}, \mathrm{TXB}_{2}$ and PG 6 oxo $\mathrm{F}_{1} \alpha$ were from Institut Pasteur Production, Marnes-La-Coquette, France. Antiserum to $\mathrm{PGF}_{2 \alpha}$ was raised in rabbits using $\mathrm{PGF}_{2} \alpha$-bovine serum albumin conjugated with carbodiimide, and was a gift from Dr Keith Hillier, University of Southampton, England. (Per cent cross reactivity at $\mathrm{B} / \mathrm{BO}=0.5$ was $\mathrm{PGE}_{2}<0.01, \mathrm{PGF}_{1} \alpha, 3.8$, $\mathrm{PGD}_{2} 6 \cdot 7,13 \cdot 14$ dihydro 15 keto $\mathrm{PGE}_{2}<0.01,13.14$ dihydro 15 keto $\mathrm{PGF}_{2} \alpha<0 \cdot 01$.) Water, Analar cyclohexane $(\mathrm{BDH})$ and Analar ethylacetate $(\mathrm{BDH})$ were all twice distilled. Nanograde methanol and silicic acid 100 Mesh (powder), were from Mallinckrodt Inc, St Louis, Missouri. RIA Luma was from LKB Instruments Ltd, Surrey, England. All other laboratory chemicals were of Analar Grade. Siliconised glassware was used throughout. KrebsRinger-Bicarbonate buffer containing $1 \mathrm{mmol} / \mathrm{l}$ glutathione (KRB) was used for tissue incubations (per litre: $\mathrm{NaCl} 7 \cdot 24$ g, $\mathrm{KCl} 0 \cdot 372 \mathrm{~g}, \mathrm{KH}_{2} \mathrm{PO}_{4} 0 \cdot 163 \mathrm{~g}, \mathrm{NaHCO}_{3} 2 \cdot 184 \mathrm{~g}$, glucose $1.8 \mathrm{~g}, \mathrm{MgSO}_{4} 7 \mathrm{H}_{2} \mathrm{O} \quad 0.32 \mathrm{~g}, \mathrm{CaCl}_{2} 2 \mathrm{H}_{2} \mathrm{O} \quad 0.184 \mathrm{~g}$, glutathione $0.3072 \mathrm{~g} ; \mathrm{pH}$ adjusted to $7 \cdot 4$ after equilibrating with $95 \% \mathrm{O}_{2} / 5 \% \mathrm{CO}_{2}$ for $15 \mathrm{~min}$ ). $0.1 \mathrm{~mol} / \mathrm{l}$ phosphate buffer $\mathrm{pH} 7 \cdot 5$ was used in the radioimmunoassays.

\section{Methods}

Alsatian dogs weighing 10-15 kg were anaesthetised with thiopentone $(7.5 \mathrm{mg} / \mathrm{kg} / \mathrm{iv})$ and halothane in nitrous oxide $70 \%$ and oxygen. Endotracheal intubation was performed and ventilation controlled. A $22 \mathrm{G}$ spinal needle was placed transorbitally into the suprachiasmatic cistern or, if this proved difficult, into the cisterna magna. Five to $7 \mathrm{ml}$ of CSF was withdrawn and fresh autologous blood $(0.6-0.75 \mathrm{ml} / \mathrm{kg})$ injected within $30 \mathrm{~s}$, with the dogs in the head-down position. The animals recovered from anaesthesia without neurological deficit and behaved and fed normally. Control animals (3), animals $3-4$ days (4), or 6-8 days (3) after subarachnoid haemorrhage were anaesthetised, heparinised and exsanguinated. Three further control animals were given indomethacin $(10 \mathrm{mg} / \mathrm{kg} / \mathrm{iv})$ under anaesthetic $10-30 \mathrm{~min}$. before exsanguination. CSF was withdrawn from the cisterna magna, and the whole brains removed quickly. The large cerebral arteries were dissected under the operating microscope and used for another related study (to be reported separately). However, the anterior and middle cerebral and basilar arteries and the choroid plexuses from some of the animals, were available for prostaglandin analyses. If immediate incubation (see below) was not feasible, brain cortex, arteries and choroid plexuses were stored at $-70^{\circ} \mathrm{C}$, and generally incubated within 7 days. CSF was collected on ice into plastic tubes containing $100 \mu \mathrm{l}$ of $\mathrm{Na}_{2}$ EDTA $(70 \mathrm{~g} / \mathrm{l})$ and acetyl salicylic acid $(5 \mathrm{~g} / \mathrm{l})$ in water. After centrifugation to remove cells, CSF was stored at $-20^{\circ} \mathrm{C}$ until assay.

Human CSF: Lumbar CSF samples were available from five patients following subarachnoid haemorrhage. For comparison lumbar CSF was also obtained from patients undergoing myelography for possible disc lesions. Although not "normal" these patients at least did not have intracranial pathology. These studies were approved by the Local Ethical Committee.

\section{LABORATORY METHODS}

Tissue incubation: Working at $4^{\circ} \mathrm{C}$ whole cortex was cleared of pial vessels, sliced at $20 \mu$ in two directions, and washed $\times$ 1 in KRB. Tissue was resuspended in KRB (approx $3 \mathrm{~g}$ tissue in $20 \mathrm{ml}$ buffer). $1 \mathrm{ml}$ of suspension was added to $4 \mathrm{ml}$ of KRB in each of four flasks and incubated at $37^{\circ} \mathrm{C}$ in a shaking water bath under $95 \% \mathrm{O}_{2} / 5 \% \mathrm{CO}_{2}$. At exactly 60 min, prostaglandin synthesis was terminated by adding $75 \mu \mathrm{l}$ of indomethacin $(1 \cdot 1 \mathrm{mg} / \mathrm{ml})$, transfer to ice, and centrifugation at $4^{\circ} \mathrm{C}$. To determine prostaglandins produced during tissue preparation, suspension was also added to $4 \mathrm{ml}$ of ice cold buffer containing indomethacin in each of two flasks. After mixing, the contents were centrifuged immediately ("zero time incubates"). Supernatants were stored at $-20^{\circ} \mathrm{C}$ for later prostaglandin analysis, and pellets for protein analysis by Lowry's method. Choroid plexuses and dissected cerebral arteries were incubated using an identical procedure.

Prostaglandin analyses of tissue incubates and CSF: Prostaglandins and $\mathrm{TXB}_{2}$ were extracted from acidified supernatant or CSF using a method based on that of Mitchell et al. ${ }^{14}$ After adding approximately $15000 \mathrm{dpm}^{3} \mathrm{H}$ $\mathrm{PGF}_{2}$ to monitor recoveries, supernatants and CSF samples (up to $7.5 \mathrm{ml}$ according to availability) were acidified to $\mathrm{pH}$ 을

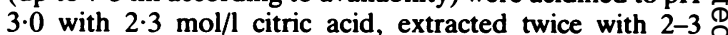
volumes of diethyl ether, and the extracts dried with $\mathrm{Na}_{2} \mathrm{SO}_{4}$. Samples were applied to minicolumns containing silicic acid $(0.5 \mathrm{~g})$ in cyclohexane $(C)$-ethyl acetate $(E)-$ methanol (M) (60:40:2 vol/vol). After washing with $5 \mathrm{ml}$ cyclohexane:ethyl acetate $(60: 40 \mathrm{vol} / \mathrm{vol})$; prostaglandins and TX were eluted under nitrogen pressure with $6 \mathrm{ml}$ of C:E:M. (60:40:20). The eluate was stored in ethanol at $-20^{\circ} \mathrm{C}$ for radioimmunoassay (RIA) of $\mathrm{PGE}_{2}, \mathrm{~F}_{2} \alpha$ and $\mathrm{TXB}_{2}$, or in acetonitrile:water (9:1 vol/vol) for 6 oxo $\mathrm{F}_{1} \alpha$. Recovery of labelled $F_{2} \alpha$ usually exceeded $75 \%$.

$R I A$ : Extracts were evaporated to dryness, taken into $0 \cdot 1$ $\mathrm{mol} / \mathrm{l}$ phosphate buffer, and $100 \mu \mathrm{l}$ assayed (in duplicate) by RIA. Lower limit of sensitivity in each RIA was 6 pg. Parallelism was demonstrable between serial dilutions of each standard prostanoid and a pooled tissue extract. Within and between batch precision was determined for replicate RIA's of pooled brain extracts of each prostanoid. Intra-assay coefficient of variation in each case was in the range 3.0 to $7.7 \%$ and interassay variation was $7.3 \%\left(F_{2} \alpha\right)$, $10.0 \%\left(\mathrm{E}_{2}\right), 12 \cdot 2 \%\left(6 \mathrm{oxO} \mathrm{F}_{1} \alpha\right)$ and $13.7 \%\left(\mathrm{TXB}_{2}\right)$. Intraassay variation was determined also for the entire extraction

Table 1 Complete extraction and radioimmunoassay procedure for nine aliquots of a CSF sample: intra-assay variation

\begin{tabular}{lll}
\hline & $\begin{array}{l}\text { Mean conc (ISD) } \\
\text { pmolll of CSF }\end{array}$ & $\begin{array}{l}\text { Cof } V \\
\%\end{array}$ \\
\hline PGF $2 \alpha \alpha$ & $420(16)$ & 10.7 \\
PGE $_{2}$ & $227(13)$ & 16.6 \\
PG $^{2}$ oxo $F_{1} \alpha$ & $305(9)$ & 8.1 \\
TXB $_{2}$ & $46(2)$ & 13.7 \\
\hline
\end{tabular}


and RIA procedure by simultaneous assay of $9 \times 7.5 \mathrm{ml}$ aliquots of a single CSF sample (human ventricular drainage sample) (table 1). Prostaglandin $D_{2}$ was kindly analysed in four CSF samples by Dr S Holgate, Senior Lecturer in Clinical Pharmacology, Southampton University Medical School.

\section{Results}

1. Effect of "mock" subarachnoid haemorrhage on prostaglandin concentrations in cisternal CSF

In six samples of cisternal CSF collected from dogs immediately before subarachnoid haemorrhage, the most abundant prostaglandin was PG 6 oxo $F_{1} \alpha$, the prostacyclin metabolite. $\mathrm{PGF}_{2} \alpha, \mathrm{PGE}_{2}$ and $\mathrm{TXB}_{2}$ were all present but in low concentration (table 2). This pattern was unchanged in the three control animals who were anaesthetised and exsanguinated, although in two of the animals increased concentrations of PG 6 oxo $F_{1} \alpha$ were observed (1271 and $1250 \mathrm{pmol} / \mathrm{l})$. Three to four days after subarachnoid haemorrhage (four dogs), all the prostaglandin concentrations were elevated. Comparing the median concentrations with those of the three control animals, the increases were: $\mathrm{PGF}_{2} \alpha \times 4 \cdot 3$; PG 6 oxo $\mathrm{F}_{1} \alpha \times 2 \cdot 3, \mathrm{TXB}_{2} \times 3 \cdot 1$. The most dramatic increase, however, was in $\mathrm{PGE}_{2}(\times 25 \cdot 5)$. By 6-8 days after subarachnoid haemorrhage only $\mathrm{PGE}_{2}$ was elevated above controls in all three animals, $\mathrm{PGF}_{2} \alpha, \mathrm{PG} 6$ oxo $F_{1} \alpha$, and $\mathrm{TXB}_{2}$ having fallen to control levels in two of the three. Prostaglandin $D_{2}$, was present at very low concentration $(31 \mathrm{pmol} / \mathrm{l})$ in cisternal CSF removed from one dog before subarachnoid haemorrhage, but increased (to a modest level) 7 days after blood injection. Indomethacin injected intravenously 10-30 min before exsanguination, decreased the concentrations of all the prostanoids in cisternal CSF, the most dramatic decrease being in the prostacyclin metabolite (124 pmol/l compared with $1250 \mathrm{pmol} / \mathrm{l}$ in controls).

2. Prostaglandin production by dog cerebral tissues in vitro: effect of mock subarachnoid haemorrhage (table 3)

The procedures used detect the capacity of cerebral tissues to synthesise prostaglandins in vitro under standardised conditions. Whole cortex from the three control animals synthesised $\mathrm{PGE}_{2}$ in greatest amount, followed by $\mathrm{PGF}_{2} \alpha$ and prostacyclin (measured as PG 6 oxo $F_{1} \alpha$ ). Some $\mathrm{TXB}_{2}$ was produced. Blood platelets produce $\mathrm{TXB}_{2}$ during aggregation and platelet contamination from blood in the incubated tissue was unavoidable, despite the wash procedures used. It seems probable that at least some of the TX produced in vitro derived from cellular components of brain tissue other than platelets however, since $\mathrm{TXB}_{2}$ was always detectable in (clear) CSF samples from the dogs. Results for individual animals showed some scatter, but subarachnoid haemorrhage appears to have had no effect on in vitro PG synthesis.

Because of limited supplies of tissues it was necessary to pool dissected arteries (and similarly choroid plexuses) from individual animals for incubation. The arteries were free of blood contamination and produced $P G E_{2}$ and $P G 6$ oxo $F_{1} \alpha$ in greatest amount. Production of $\mathrm{PGE}_{2}$ by the subarachnoid haemorrhage "pool" was greater than that of the controls and there was a slight decrease in PG 6 oxo $F_{1} \alpha . P G E_{2}$ and 6 oxo $F_{1} \alpha$ were also the main products of the choroid plexuses, but for these no difference between the control and subarachnoid haemorrhage pools was apparent. Unavoidably, the choroid plexus incubates were contaminated with blood. Perhaps this accounted for some of the $\mathrm{PGF}_{2} \alpha$ produced, although a greater production of $\mathrm{TXB}_{2}$ might also have been anticipated (see below).

Table 2 Prostaglandins and thromboxane $B_{2}$ in dog cisternal CSF

\begin{tabular}{|c|c|c|c|c|c|}
\hline \multirow[t]{2}{*}{ Experiment (no of animals) } & & \multicolumn{4}{|c|}{ CSF prostaglandins (pmol/l) } \\
\hline & & $P G F_{2} \alpha$ & $E_{2}$ & 6 oxo $F_{/ \alpha}$ & $T X B_{2}$ \\
\hline CSF collected before SAH (6) & $\begin{array}{l}\text { Median } \\
\text { Range }\end{array}$ & 62 & $\begin{array}{l}57 \\
34-128\end{array}$ & $\begin{array}{l}208 \\
181-561\end{array}$ & $\begin{array}{l}94 \\
62-162\end{array}$ \\
\hline $\begin{array}{l}\text { Controls-terminal (3) } \\
\text { SAH 3-4 days (4) } \\
\text { SAH 6-8 days (3) }\end{array}$ & $\begin{array}{l}\text { Median } \\
\text { Range } \\
\text { Median } \\
\text { Range } \\
\text { Median } \\
\text { Range }\end{array}$ & $\begin{array}{l}107 \\
62-138 \\
454 \\
417-643 \\
133 \\
130-158\end{array}$ & $\begin{array}{l}60 \\
51-122 \\
1552 \\
1506-2701 \\
377 \\
388-1416\end{array}$ & $\begin{array}{l}1250 \\
240-1271 \\
2912 \\
1673-6505 \\
731 \\
394-2942\end{array}$ & $\begin{array}{l}81 \\
62-275 \\
248 \\
175-356 \\
73 \\
62-73\end{array}$ \\
\hline $\begin{array}{l}10-30 \text { min after indomethacin (3) } \\
\text { (indomethacin-treated controls) }\end{array}$ & $\begin{array}{l}\text { Median } \\
\text { Range }\end{array}$ & $\begin{array}{l}51 \\
45-59\end{array}$ & $\begin{array}{l}34 \\
17-48\end{array}$ & $\begin{array}{l}124 \\
100-151\end{array}$ & $\begin{array}{l}76 \\
35-140\end{array}$ \\
\hline
\end{tabular}

SAH = "mock" subarachnoid haemorrhage. 
Table 3 Prostaglandin and thromboxane $B_{2}$ synthesised by dog cerebral tissues in vitro

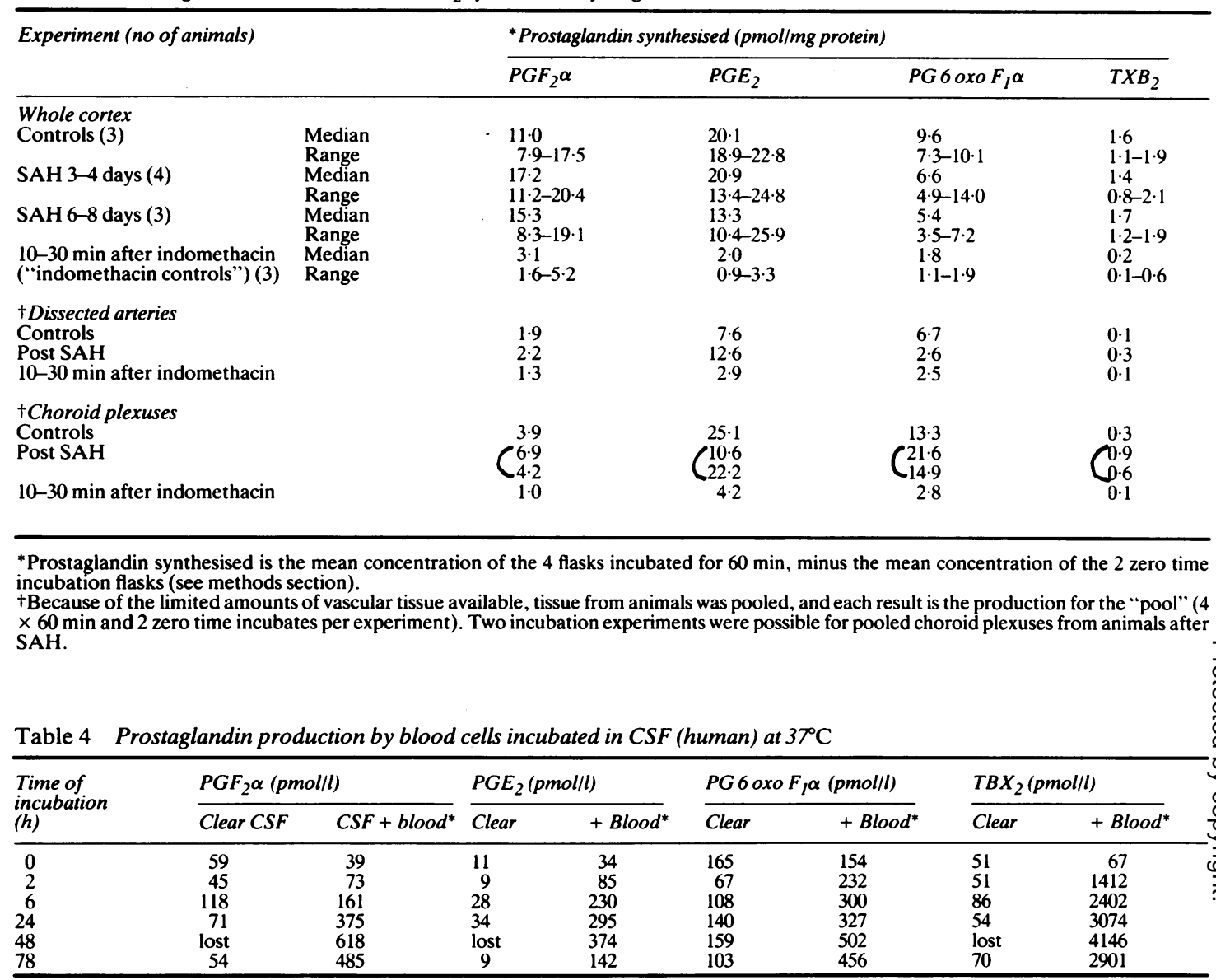

*Approx $300000 \mathrm{RBC}$ per $\mathrm{mm}^{3} \mathrm{CSF}$.

Table 5 Prostaglandins and thromboxane $B_{2}$ in lumbar CSF collected from five patients following SAH

\begin{tabular}{|c|c|c|c|c|c|}
\hline \multirow[t]{2}{*}{ Patient } & \multirow{2}{*}{$\begin{array}{l}\text { Day after } \\
\text { SAH }\end{array}$} & \multicolumn{4}{|c|}{ Prostaglandin concentration (pmol/l) } \\
\hline & & $F_{2} \alpha$ & $E_{2}$ & 6 oxo $F_{1} \alpha$ & $T X B_{2}$ \\
\hline $\begin{array}{l}1 \\
2 \text { (3rd bleed }) \\
3 \\
4 \\
5\end{array}$ & $\begin{array}{l}8 \\
8 \\
6 \\
6 \\
9\end{array}$ & $\begin{array}{r}852 \\
1094 \\
1661 \\
259 \\
3869\end{array}$ & $\begin{array}{r}471 \\
740 \\
1719 \\
196 \\
5126\end{array}$ & $\begin{array}{r}848 \\
1552 \\
2570 \\
540 \\
4113\end{array}$ & $\begin{array}{r}81 \\
70 \\
178 \\
16 \\
173\end{array}$ \\
\hline $\begin{array}{l}\text { Mean } \\
\pm \text { SEM }\end{array}$ & & $\begin{array}{l}1548 \\
\pm 620\end{array}$ & $\begin{array}{l}1651 \\
\pm 905\end{array}$ & $\begin{array}{l}1924 \\
\pm 648\end{array}$ & $\begin{array}{l}103 \\
\pm 32\end{array}$ \\
\hline $\begin{array}{l}{ }^{*} \text { Controls } \\
\pm \text { SEM } \\
\text { No. } \\
\text { Range }\end{array}$ & & $\begin{array}{l}87 \\
5 \cdot 67 \\
11 \\
56-107\end{array}$ & $\begin{aligned} & 28 \\
& 4.94 \\
& 15 \\
&< 14-74\end{aligned}$ & $\begin{array}{l}378 \\
47 \cdot 23 \\
19 \\
130-848\end{array}$ & $\begin{array}{l}103 \\
19 \cdot 76 \\
13 \\
13-240\end{array}$ \\
\hline$\dagger$ & & $\mathrm{p}<0.01$ & $\mathrm{p}<0.01$ & $\mathrm{p}<0.001$ & NS \\
\hline
\end{tabular}

*Patients having myelography for possible lumbosacral disc lesions. Samples removed above the site of disc herniation.

tStudent's $t$ test. NS = not significant. 
Indomethacin administration decreased in vitro production of all the prostanoids by whole cortex, arteries, and choroid plexuses. The less pronounced effect of indomethacin on the arteries and choroid plexus may reflect washout of the indomethacin from these much thinner tissues-indomethacin does not produce irreversible inhibition of prostaglandin synthesis. ${ }^{15}$

\section{Prostaglandin production by blood cells incubated in $\mathrm{CSF}$ at $37^{\circ} \mathrm{C}$ (table 4)}

Blood platelets release TX during aggregation, and neutrophils and other white blood cells produce a range of prostanoids. To make some assessment of the maximal contribution blood cells themselves might make to the prostanoid content of CSF after subarachnoid haemorrhage, fresh whole blood was mixed quickly with human CSF to give a red cell count of approximately 300000 per $\mathrm{mm}^{3} \mathrm{CSF}$ - that is of the order found in lumbar CSF after a severe subarachnoid haemorrhage. Aliquots were incubated in siliconised tubes at $37^{\circ} \mathrm{C}$ and prostaglandin production was terminated at timed intervals by addition of acetyl salicylic acid and freezing $\left(-20^{\circ} \mathrm{C}\right)$. All prostaglandins were synthesised for up to 48 hours (table 4), the lower concentrations at $78 \mathrm{~h}$ probably reflecting loss of immunoreactivity with prolonged incubation. $\mathrm{TXB}_{2}$ was the main product. Only a small increase in PG 6 oxo $F_{1} \alpha$ was observed. This experiment of course makes no allowance for removal of prostaglandins from CSF which would occur in vivo.

\section{Prostaglandins in lumbar CSF collected from five patients following subarachnoid haemorrhage}

Six to 9 days following subarachnoid haemorrhage all prostaglandins were significantly increased in the lumbar CSF when compared with "control" CSF collected from orthopaedic patients (table 5) and the changes resembled closely those seen in dogs. $\mathbf{T X B}_{2}$ concentration was generally quite low after 8 days, but in one sample collected within $24 \mathrm{~h}$ after a bleed, high levels were observed (5568 pmol/l). $\mathrm{PGD}_{2}$ assayed in a single sample, was present in low concentration (91 pmol/l)

\section{Discussion}

Our main findings are firstly that the PG spectra of CSF in the dog is not an accurate reflection of in vitro PG production by cerebral cortex, cerebral arteries or choroid plexus. Choroid plexus and cerebral arteries have a similar spectrum of PG synthetic activity (see also refs $16,17,18)$. Secondly the proportions of the various PG's/TXB ${ }_{2}$ in CSF in man (see also ref 19) and $\operatorname{dog}$ are similar. Thirdly, that subarachnoid haemorrhage results in a great increase in the whole spectrum of PG's/TXB ${ }_{2}$ in the CSF in both man and dog, not just $\mathrm{PGF}_{2} \alpha^{20-22}$ and a proportionately greater increase of $\mathrm{PGE}_{2}$ in both species. Fourthly, the in vitro production of $\mathrm{PG}$ 's/TXB $\mathbf{T X}_{2}$ by cerebral cortex and choroid plexus was not affected by subarachnoid haemorrhage, but there is some support for increased $\mathrm{PGE}_{2}$ synthesis by the larger cerebral arteries, with depression of prostacyclin synthesis in vitro.

Are the concentrations of prostaglandins $/ \mathrm{TXB}_{2}$ sufficient to account for cerebral vasoconstriction some days after subarachnoid haemorrhage? Our parallel studies in dogs have shown that cerebral arterial narrowing to less than $67 \%$ of control occurs in $20 \%$, and to between $67 \%$ and $100 \%$ in $30 \%$ of dogs 7 days after subarachnoid haemorrhage. (Graham, Matear, Pickard, McPherson, Tamura and Fitch, unpublished observations.) We have no data on cerebral blood flow changes following subarachnoid haemorrhage in the dog; in the baboon, baseline CBF does not change but reactivity is impaired one week after subarachnoid haemorrhage. ${ }^{2}$ Consistent with these findings, the in vitro contractile reactivity of cerebral arteries taken from our dogs is altered by subarachnoid haemorrhagethe response to amines is enhanced but the response to $\mathrm{pH}$ changes and sodium-loading is depressed (Pickard and Perry, unpublished observations).

Extrapolation of effective vasoconstrictor doses for prostaglandins/TXA ${ }_{2}$ from other species or from in vitro analysis must be done with care. Brandt et al ${ }^{23}$ have shown that there is considerable individual variability in the spectrum of reactivity of cerebral arteries from man in vitro to different stimuli such as high potassium, prostaglandins and biogenic amines (serotonin, noradrenaline). However, in both dog and man, in vitro contractions of cerebral arteries are produced with $\mathrm{PGF}_{2} \alpha$ and $\mathrm{PGE}_{2}$ of concentrations above $100 \mathrm{nmol} / 1.2425$ Lesser concentrations may produce just detectable responses, and may potentiate the effects of other vasoconstrictor agents at these low levels. The combined concentrations of the two cerebral vasoconstrictors $\mathrm{PGF}_{2} \alpha$ and $\mathrm{PGE}_{2}$ of around $2 \mathrm{nmol} / \mathrm{l}$ in cisternal CSF 3 days and $0.5 \mathrm{nmol} / 1$ 7 days after subarachnoid haemorrhage in the dog, and of around $3 \mathrm{nmol} / \mathrm{l}$ in lumbar CSF in man 7 days after subarachnoid haemorrhage, seem a little low for potent vasoconstrictor action. The low concentrations of $\mathrm{TXB}_{2}$ make the more potent $\mathrm{TXA}_{2}$ an even less likely candidate at 3-7 days after subarachnoid haemorrhage-its concentration is much higher immediately following a bleed but subsides very rapidly. Unfortunately lumbar CSF is an inexact mirror of what is happening around the cerebral arteries, closeted in their subarachnoid haematoma, 
and changes in lumbar $\mathrm{PGF}_{2} \alpha$ levels do not correlate with clinical state or presence of vasospasm. ${ }^{20} 21$

Although CSF PG 6 oxo $F_{\alpha} \alpha$ increases following subarachnoid haemorrhage, we, Maeda et al ${ }^{12}$ and Sasaki et al ${ }^{11}$ find that production of this metabolite of prostacyclin by isolated arteries is depressed following subarachnoid haemorrhage by around $60 \%, 34 \%$ and $50 \%$ respectively. However, some caution is needed before accepting these results. First, following subarachnoid haemorrhage it is technically more difficult to dissect out cerebral arteries, even using microsurgical technique, because of organised clot and fibrous tissue and the endothelium might become injured even though no damage was seen on light microscopic examination of arteries used in these studies. Secondly, different conditions of in vitro incubation and different analytical procedures were used by the three groups, and whereas Maeda et $^{12}$ found that $\mathrm{PGF}_{2} \alpha$ production was $9 \%$ and $\mathrm{PGE}_{2} 24 \%$ of that of PG 6 oxo $F_{1} \alpha$, the corresponding figures in our study were $28 \%$ and $108 \%$. Thus the choice of conditions may influence the pattern of production in vitro. A third consideration is that prostacyclin synthesis within vessels of differing calibre may differ after subarachnoid haemorrhage-decreased production in larger arteries perhaps being a consequence of spasm, and increased production occurring possibly in smaller vessels. Finally it remains to be shown what level of impairment of prostacyclin synthesis is biologically significant. Clearly more work is needed.

Several factors may have combined to increase CSF prostaglandin concentrations 3-4 days after subarachnoid haemorrhage. Blood cells themselves produce a range of prostanoids, and the increased concentration of $\mathrm{PGF}_{2} \alpha$ after subarachnoid haemorrhage and the very modest increase in $\mathrm{TXB}_{2}$ could well be accounted for by production by extravasated blood cells. If blood were the principal source however, higher concentrations of $\mathrm{TXB}_{2}$ might have been anticipated. The large changes in $\mathrm{PGE}_{2}$ and $\mathrm{PG} 6$ oxo $F_{1} \alpha$ observed moreover require additional explanation. Some of the $\mathrm{PGE}_{2}$ may have derived from macrophages, since subarachnoid haemorrhage induces a brisk macrophage response, and phagocytosis of extravasated blood cells is maximal 5-7 days after the bleed. $\mathrm{PGE}_{2}$ is a major prostanoid product of macrophages. ${ }^{26}$

A further possibility is that increased prostaglandin synthesis by some element of brain tissue may have contributed to the increased levels. Unfortunately arachidonic acid release and metabolism is increased variably by terminal ischaemia, brain dissection, and tissue handling, and measurement of prostaglandin levels in dissected tissues directly, produces uninterpretable results which bear little relationship to their levels in vivo (see ref 9 for review). Comparison of the capacities of tissues to produce PG's under standardised conditions in vitro (as in the present study), is a more helpful and acceptable alternative, but such studies are quite crude. Any changes in PG production induced in tissues after subarachnoid haemorrhage might be reversed readily under incubation conditions, and masked. Perhaps this explains why no differences were demonstrable in vitro for prostaglandin production by whole cortex or choroid plexuses between controls and subarachnoid haemorrhage animals. Both Maeda et al ${ }^{12}$ and ourselves find that $\mathrm{PGE}_{2}$ production by cerebral arteries is enhanced following subarachnoid haemorrhage-if it were, then the raised concentration of $\mathrm{PGE}_{2}$ in CSF might reflect an abnormal arterial response to subarachnoid haemorrhage, rather than being a primary agent itself in inducing such a response. Finally, impaired clearance of prostanoids from the subarachnoid space probably contributed to raised CSF levels. This would result in part from saturation of the choroidal and extrachoroidal facilitated transport system for the primary prostaglandins and $\mathrm{TXB}_{2}, 2728$ and in part because of impaired clearance through the arachnoid granulations and obstruction to bulk flow of CSF into the dural venous sinuses. ${ }^{29}$

The preliminary observations with indomethacin are interesting. Although intravenous injection decreased the concentrations of all measured prostanoids in cisternal CSF, the decrease in PG 6 oxo $F_{1} \alpha$ was very rapid and most dramatic when compared with controls. This supports the notion that the turnover of prostacyclin in brain is normally rather rapid. In vitro production-notably of $\mathrm{PGE}_{2}$ and of PG 6 oxo $F_{1} \alpha$-was depressed in all the tissues examined. These findings fit well with Pickard's observations and support his proposal that prostacyclin has a role in the control of CBF. ${ }^{89}$ However other nonsteroidal anti-inflammatory agents have more complex effects on the cerebral circulation. ${ }^{9}$ Clearly more work with this group of compounds is needed and should be combined with biochemical studies.

A preliminary communication has been presented to the Medical Research Society, Clinical Science Vol. 63 , No. 3, September 1982. This work was supported by The National Fund for Research into Crippling Diseases and by the Medical Research Council.

\section{References}

1 Wilkins RH. (ed) Cerebral Arterial Spasm. Baltimore: Williams \& Wilkins, 1980. 
2 Pickard JD, Boisvert DPJ, Graham DI, Fitch W. Late effects of subarachnoid haemorrhage on the response of the primate cerebral circulation to drug-induced changes in arterial blood pressure. J Neurol Neurosurg Psychiatry 1979;42:899-903.

3 Pickard JD, Matheson M, Patterson J, Wyper D. Prediction of late ischaemic complications after cerebral aneurysm surgery by the intraoperative measurement of cerebral blood flow. J Neurosurg 1980; 53:305-8.

4 Pickard JD, Vinall P, Simeone FA. Prostaglandins and Cerebral Vasospasm-a problem of interpretation. Surg Forum 1975;26:496-8.

5 Bell BA, Kendall BE, Symon L. Computed tomography in aneurysmal subarachnoid haemorrhage. J Neurol Neurosurg Psychiatry 1980;43:522-4.

6 Asano T, Tanishima T, Sasaki T. Possible participation of free radical reactions initiated by clot lysis in the pathogenesis of vasospasm after subarachnoid haemorrhage. In Ref (1) pp 190-201.

7 Moncada S, Vane JR. The role of prostacyclin in vascular tissue. Fed Proc 1979;38:66-71.

8 Pickard JD, MacKenzie ET. Inhibition of prostaglandin synthesis and the response of baboon cerebral circulation to carbon dioxide. Nature 1973;245:187-8.

9 Pickard JD. Role of prostaglandins and arachidonic acid derivatives in the coupling of cerebral blood flow to cerebral metabolism. J Cerebral Blood Flow Metab 1981;1:361-84.

10 Boullin DJ, Bunting S, Blaso WP, Hunt TM, Moncada S. Response of human and baboon arteries to prostaglandin endoperoxides and biologically generated and synthetic prostacyclin: their relevance to cerebral arterial spasm in man. Brit J Clin Pharmacol 1979;7:139-47.

11 Sasaki T, Sei-Itsu M, Wakai S, Asano T, Sano K. Evaluation of prostaglandin biosynthetic activity in canine basilar artery following subarachnoid injection of blood. J Neurosurg 1981;55:771-8.

12 Maeda Y, Tani E, Miyamoto T. Prostaglandin metabolism in experimental cerebral vasospasm. $J$ Neurosurg 1981;55:779-85.

13 Granstrom E. Assay methods for prostaglandins and thromboxanes. Adv Prostaglandin Thromboxane Res 1980;6:69-76.

14 Mitchell MD, Flint AP, Bibby J, Brunt J, Arnold JM, Anderson ABM, Turnbull AC. Plasma concentrations of prostaglandin during late human pregnancy: influence of normal and preterm labour. J Clin Endocrinol Metab 1978;46:947-51.

15 Hornstra G, Haddeman E, Don JA. Blood platelets do not provide endoperoxides for vascular prostacyclin production. Nature 1979;279:66-8.

16 Abdel-Halim MS, von Holst H, Meyerson B, Sachs C,
Anggard E. Prostaglandin profiles in tissue and blood vessels from human brain. J Neurochem 1980;34:13313.

17 Goehlert UG, Ng Ying Kin NMK, Wolfe LS. Biosynthesis of prostacyclin in rat cerebral microvessels and the choroid plexus. $J$ Neurochem 1981;36:1192-201.

18 Hagen AA, White RP, Robertson JT. Synthesis of prostaglandins and thromboxane $\mathrm{B}_{2}$ by Cerebral Arteries. Stroke 1979;10:306-9.

19 Abdel-Halim MS, Ekstedt J, Anggard E. Determination of prostaglandin $F_{2} \alpha, E_{2}, D_{2}$ and 6-keto $F_{1} \alpha$ in human cerebrospinal fluid. Prostaglandins 1979;17:405-9.

20 La Torre E, Patrono C, Fortuna A, Grossi-Belloni D. Role of $\mathrm{PGF}_{2}$ in human cerebral vasospasm. $J$ Neurosurg 1974;41:293-9.

${ }^{21}$ Hagen AA, Gerber IN, Sweeley CC, White RP, Robertson JT. Level and disappearance of Prostaglandin $\mathrm{F}_{2} \alpha$ in cerebral spinal fluid: a clinical and experimental study. Stroke 1977;8:672-5.

22 Wolfe LS, Mamer OA. Measurement of PGF $\alpha$ levels in human cerebrospinal fluid in normal and pathological conditions. Prostaglandins 1975;9:183-92.

23 Brandt L, Ljunggren B, Andersson KE, Hindfelt B. Individual variations in response of human cerebral arterioles to vasoactive substances, human plasma, and CSF from patients with aneurysmal SAH. $J$ Neurosurg 1981;55:431-7.

24 Allen GS, Henderson LM, Chou SN, French LA. Part 1: In vitro Contractile Activity of Vasoactive Agents on Canine Basilar and Middle Cerebral Arteries. J Neurosurg 1974;40:433-41.

25 Toda N, Miyazaki M. Response of isolated dog cerebral and peripheral arteries to prostaglandins after application of aspirin and polyphloretin phosphate. Stroke 1978;9:490-8.

26 Stenson WF, Parker C. Prostaglandins, macrophages and immunity. J Immunol 1980;125:1-5.

27 Bito LZ, Davson H, Hollingsworth JR. Facilitated transport of prostaglandins across the bloodcerebrospinal fluid and blood-brain barrier. J Physiol (London) 1976;256:273-85.

28 DiBenedetto FE, Bito LZ. The active transport of thromboxane $\mathrm{B}_{2}\left(\mathrm{TXB}_{2}\right)$, Prostacyclin $\left(\mathrm{PGI}_{2}\right)$ and 6keto-PGF ${ }_{1} \alpha$ by some mammalian tissues. Physiologist 1980;23:171(911A).

29 Butler AB, Maffeo CJ, Johnson RN, Bass NH. Alteration of CSF outflow in acute subarachnoid haemorrhage: effect of blood components on outflow resistance and vesicular transport of CSF in arachnoid villus endothelium. In: Cervos-Navarro J, Fritschka E, eds. Cerebral Microcirculation and Metabolism. New York: Raven Press, 1981:409-14. 